\title{
Critical Failure Factors in Selling Shoplots towards Sustainability of New Township Development
}

\author{
N.M. Tawil ${ }^{1}$, N.I. Mohamad ${ }^{2}$, I.M. Usman ${ }^{3}$, M. M. Tahir ${ }^{4}$, M.A. Othuman Mydin ${ }^{5}$ \\ ${ }^{1,2,3,4}$ Faculty of Engineering and Built Environment, Universiti Kebangsaan Malaysia 43600 UKM \\ Bangi, Selangor Malaysia \\ ${ }^{5}$ School of Housing, Building and Planning, Universiti Sains Malaysia, 11800, Penang, Malaysia
}

\begin{abstract}
The focus of this research is to identify the critical factors of shop houses sale failure in Nilai New Township. The critical factors of sale failure of commercial property types, shop houses in new township need to be discover as reported by Valuation and Property Services Department (JPPH) showed 5,931 units of shop houses in Malaysia is currently completed but remained unsold where Johor was recorded as the highest with unsold units followed by Negeri Sembilan. Thus Nilai New towship is chosen as research sample for unsold shop houses units due to its strategic location which is near to KLIA, International Sepang Circuit, educational instituitions and surrounded by housing scheme but yet still has numbers of unsold units. Data was gathered from survey question between developers, local authority, purchasers/tenant and local residents.. Generally, the factors of sale failure are economy, demography, politic, location and access, public and basic facilities, financial loan, physical of product, current stock of shop houses upon completion, future potential of subsale and rental, developer's background, promotion and marketing, speculation and time.
\end{abstract}

\section{Introduction}

In a new township, dilemma occurs when consider the launch of commercial development property. Spectacular is one of the factors in deciding development in new area. Some spectacular give positive impact and a fast grow of New Town Ship, but sometimes the new township is not as what reported. This related to oversupply of building which effect the energy economy growth. Although it may happen everywhere but with different degree of seriousness. As mentioned by Ramabodu et al. [1] in some cities and urban development in South Africa. The developments focus strongly on converting offices and even industrial buildings into residential spaces as well as the upgrading of existing stock. While in UK, Swallow [2] stated that buildings may become unoccupied for a variety of reasons, and that some will be physically or functionally obsolete and may be beyond economic repair or adaptation.

In Malaysia, JPPH [3,4] from its report, showed the scenario of shop houses oversupply in peninsula Malaysia. JPPH report on quarter II, 2011 showed 5,931 units at the value of RM 1.690 billion of completed shop houses remained unsold. In Selangor as example, Bukit Beruntung was once spectaculate as a good New area which hoped to become new PJ with new national airport location [5]. Unfortunately, the expansion and development is unexpected slow due to the changes of New airport is based in KLIA and Banting area. 
As in New Township Negeri Sembilan with 622 units unsold shop houses is recorded as the second highest after Johor and this number contibute to $10.5 \%$ of overall amount unsold units in Malaysia. Most of the completed and unsold units of shoplots in Negeri Sembilan is situated at the district of Seremban.

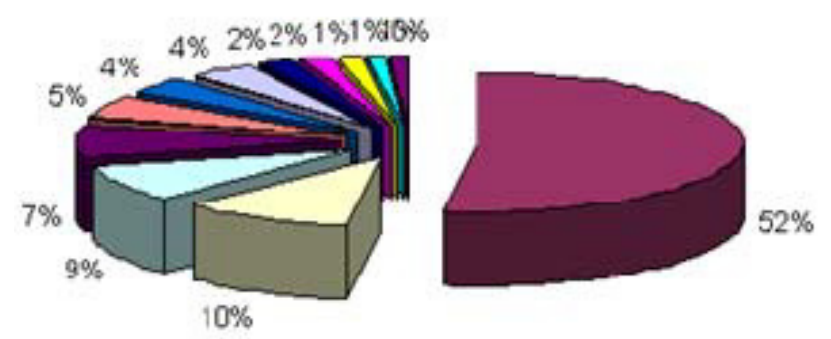

Figure 1: Overhang Shoplots in Malaysia

In relation to this, this paper is intended to examine the energy economics towards critical factor of shop houses sale failure in Bandar Baru Nilai (BBN). Even situated near KLIA, International Sepang Circuit, educational instituitions and surrounded by housing schemes but BBN still has numbers of completed units which remained unsold at Bandar Baru Nilai. BBN is a well planned new township with specific area marked for each development types which are commercial area, housing scheme and educational instituition. There are about 26 numbers of housing scheme in BBN which supposedly to support the development of shop houses here but the current scenario is in contrary.

Generally, the aim of this research is to achieve a few objective that is to identify and review the pattern of shop houses construction in new township and further up to determine the critical factor of shop houses sale failure in new township.

It is hoped to benefit the construction industry players particularly the developers in guiding them for the best investment return, local authority in assisting them to permit only sound application that meet the need of the area for shop houses development and researcher in providing the input for future research. Moreover, this research may decrease the risk of shop houses oversupply in the market

Basicly, a successful sale factor is influenced by macro and micro factor. Macro factor includes economy, demography and politic while micro factors are location and access, public and basic facility, financial loan, physical features, current stock, future potential, developer's backgroud, promotion and marketing, speculation and time.

\section{Micro Factors of Sale Failure}

There are lots of debate and discussion for failure factors of shoplots. There are four types of risk in real estate investment and these includes time and location risk which need to be managed for product succeed. Tuner [7] repeat three times that location, location and location is the main successful indicator for a property product. This is also mentioned by Dobson and Goddard [8] that location factor is among a considerations in investment decision. Other than that, time factor is also important as it indicate the situation at the time a property is launched [9].

Public urban transport like light rail, metro and other urban rail transit systems can play a significant role in improving the attractiveness and quality of property. Therefore the introduction of a new station has a positive impact on property values of all types [10]. On the average, annual property value increase at the area of bus rapid transit especially places within walking distance from the system $[11,12]$.

One-third of lending by UK bank worldwide is to real estate sector which means common form of property financing is through bank loan [13]. Again this may relate to current policy and financial loan $[14,15]$. Moreover, physical attraction of a building also play an important role in building selling 
point as there is perception that a building need replacement simply because it is old and inefficient [16]

It is important for the developer to do a study on the current stock of property to estimate the future's need in avoiding oversupply and further more reduce their risk of loss in investment [17]. Future potential of a commercial property like rental value expectation is one of criteria that investor look into when considering to buy commercial property [18]. Dobson and Goddard [8], also belived that the supply of properties to let or sell in each area depends on the area's rent and price.

Promotion and marketing strategy is a way to increase sale and this is proved by [16] in his findings where The results indicate that a high offer price is more likely to result in a high ratio of transaction price to expected price compared to a low offer price [17].

Speculation manipulate demand over real estate investment which creates speculative bubble [18]. Speculative bubble drives further demand and stimulate sale but somehow at some point the demand decreases or stagnates where at the same time supply continue increases and this will result in oversupply $[19,20]$

\section{Conclusion}

In conslusion, before the development of commercial building in a new development area, these two factors need to be consider. The development of commercial property cannot stand alone and need to be supported by its surrounding and it is better if the area is a center of attraction. This will make it more valuable and interesting for investment. That explained the reason location and access be a main factor of successful sale of shop houses and followed by public and basic facility factor and demography which is all related to a good condition and environment of a location.

\section{Acknowledgment}

This research is granted by Solar Energy and Renewable Institute, Universiti Kebangsaan Malaysia (OUP-2012-064) and incentive university industry / community (INDUSTRI-2012-034).

\section{References}

1. M.S. Ramabodu, B.G. Kotze, J.J.P. Verster (2007), Diversity And Value In Africa's Real Estate: Challenges Facing Property Development In South Africa, Journal Of Property Investment \& Finance, 2007.

2. Peter Swallow, Managing Unoccupied Buildings And Sites. Journal Of Property Investment \& Finance, 2005.

3. Laporan Stok Harta Tanah . Jadual Stok Harta Perdagangan Q4 2010, Jabatan Penilaian \& Perkhidmatan Harta, 2010.

4. Sabariah Eni \& Zaharah Manaf, Sustainable Urban Development- its Impact on Property Development an Local Revenue. International Conference on Local Goverment 2006. Sutera Harbour Kota Kinabalu Sabah. 22-24 August 2006, 2006.

5. Turner, A, Building Procurement. London: Macmillan Press Ltd, 1997.

6. S. M. Dobson \& J. A. Goddard, Commercial Property and The Location. Location Science, 1994.

7. Nur Faizal Abdullah, Faktor Yang Dipertimbangkan Sebelum Membangunkan Harta Tanah Perumahan Dari Perspektif Pemaju. Unpublished Thesis. UTM, Skudai: Fakulti Kejuruteraan Dan Sains Geoinformasi, 2006.

8. Francesca Pagliara \& Enrica Papa, Urban Rail Systems Investments: An Analysis Of The Impacts On Property Value And Residents' Location. Journal Of Transport Geography, 2011. 
9. Kicki Bjorklund, John Mattson Fastighets AB, Lidingo, Sweden, John Alex Dadzie \& Mats Wilhelmsson (2006). Offer Price, Transaction Price And Time-On-Market. Property Management Building and Real Estate Economics, Royal Institute Of Technology, 2006.

10. Noor Akmal Adillah Ismail, Effectiveness Cost Estimation System practice The Quantity Surveyors Malaysia, Unpublished Thesis. UTM: Faculty of Civil Engineering, 2005.

11. Norharnila Rusli, Salah Urus Risiko Dalam Projek Pembangunan Projek Perumahan: Kajian Ke Atas Projek Terbengkalai Di Malaysia,Unpublished Thesis. UTM, Skudai: Fakulti Kejuruteraan Awam, 2006.

12. Faridah Abdullah, Kajian Pemulihan Projek Pembangunan Kediaman Terbengkalai Di Dalam Wilayah Persekutuan Kuala Lumpur. Unpublished Thesis. UTM, Skudai: Fakulti Kejuruteraan Awam, 2005.

13. Abd Ghani Khalid, Model Ramalan Kos Pembinaan. Laporan Akhir Penyelidikan Kontrak UTM, Skudai, 2008.

14. Google Books, Using Multi- Criteria Decision Analysis In Natural Resource Management, 2011.

15. Hishamuddin Mohd Ali, Pembentukan Model Penawaran Optimum Bagi Harta Tanah Perdagangan Di Taman Perumahan. Laporan Akhir Penyelidikan. UTM, Skudai, 2007.

16. Irdayatiabdul Air, Kadar Ketersediaan Tanah Untuk Pembangunan Perumahan Di Kawasan Bandarmenurut Rancangan Tempatan Daerah: Keberkesanannya Dari Perspektif Pemaju.Unpublished Thesis. UTM, Skudai: Fakulti Kejuruteraan Dan Sains Geoinformasi, 2005.

17. Ramon Munoz-Raskin, Walking Accessibility to Bus Rapid Transit: Does it affect property values? The Case of Bogota, Colombia. Journal of Transport Policy, 2010.

18. Neil Crosby and CathyHughes, The Basis of Valuations for Secured Commercial Property Lending in the UK. Journal of European Real Estate Research, 2011.

19. Aminah Md Yusof \& Ismail B. Omar, Analisis Kitaran Ekonomi dan Industri Pembinaan di Malaysia.Laporan Akhir Penyelidikan. UTM, Skudai, 2007.

20. Peter Bullen and Peter Love, Factors Influencing the Adaptive-use of Buildings. Journal of Engineering, Design and Technology, 2009. 